\title{
Effects of Exposure to a Variety of Waste on Human Health
}

\section{- A Review}

\author{
Saeid Jafarzadeh-Ghoushchi, Shadi Dorosti
}

\begin{abstract}
The amount of waste has been greatly increased due to population growth and industry development, which has an undeniable effect on human health and the environment. The way of handling the situation becomes a major problem since inappropriate management is likely to have devastating effects on public health and the environment. The present study reviews the side effects of wastes on the human and determines the countries producing the largest amounts of waste. To do so, published papers on the effects of waste on human were reviewed using the data available on the ISI-Web of Science. The number of articles on the subject as on February 21, 2016 were 436. These papers were categorized into four main classes based on the waste type (medical waste, municipal waste, electronic waste, and industrial waste), and each category was separately analyzed. According to the results America, Jordan and Kuwait have the highest amounts of medical waste production. Thus, their people have more exposure to diseases such as respiratory problems, skin diseases, hepatitis $A$ and $B$, cancer and so forth. The highest municipal wastes are produced in countries such as Norway and Mexico. Their people are exposed to diseases such as breath, respiratory and reproductive problems. The amount of industrial waste production in Asia (countries such as China, Japan, South Korea, India and Australia) is higher than other Asian countries. Recommendations for proper management according to the conducted research were stated. Finally, gaps and suggestions in this area were identified and mentioned. This research can help those who are interested in studying the effects of wastes.
\end{abstract}

KEYWORDS: waste management, health, exposure to wastes.

This article may be cited as: Ghoushchi SJ, Dorosti S. Effects of Exposure to a Variety of Waste on Human Health - A Review. J Liaquat Uni Med Health Sci. 2017;16(01):03-9.

doi: 10.22442/jlumhs. 171610497

\section{INTRODUCTION}

Lately, with the increment of population, waste generation in different types has increased a lot all because of the actions of the human-beings, changes that are related to their lives and their patterns of consumption ${ }^{1}$. Thus, waste has become a serious problem amongst the most critical global environmental issues and being worry about it is getting greater.

If wastes are not managed appropriately, it can threaten the lives of humankind and other creatures by polluting the water, soil and atmosphere. Climate change leads to the infection of all resources that are required for survival. As a result, wastes can eclipse the living through spreading the sicknesses ${ }^{2}$. That is the reason why public concern has been arising about the waste effects on human health and all the government and health writers are under pressure to evidence all side effects of wastes that are produced by all human activities. Recently, a number of articles and manuscripts published in association with waste effects on human health were investigated in some studies. Attempting to find a solution to decrease the adverse effects is obvious.

One can notice that such mismanagements of wastes have a direct effect on health. This can be seen most notably in developing countries. However, some people believe that they cannot have a direct effect on human health. Thus, everyone tries to prove the direct effects of wastes on human health.

Waste is any kind of material that creates some stuff, known as scrap, sewage or other undesirable additional and complex mixtures that appear after using a procedure or any kind of substance that is intrinsically hazardous to health.

In this article, all written about the effects of wastes on human health have been collected, the gaps have been identified, and the best known solution has been proposed.

The structure of the present study is as follows:

The wastes are categorized into four main sections.

The direct and indirect influence of wastes on human health is evaluated and the results are presented.

The most recent information on different waste producing countries is summarized.

The treatment of each kind of wastes is proposed. In the final section, the conclusions and suggestions are provided to develop the present study.

Definition and classification of waste types:

Published articles are reliable resources to check the 
latest studies on the related topic. Waste classified according to the available data from the ISI-Web of Science as health center wastes, municipal wastes, electronic wastes, and industrial wastes. Figure 1 presents the number of articles and studies in this field. Most of them are conducted on municipal wastes and fewer studies on industrial wastes. This can be one of the gaps in this field ${ }^{3}$. substances that can spread diseases as well as the direct or indirect effects on the staff dealing with healthcare, the sick people, the individuals who interact with the waste and the environment.

Hospital wastes are divided into hazardous and non-hazardous types. The none hazardous are all those wastes that consist of domestic and municipal wastes and the hazardous ones are all those wastes

\section{FIGURE I: THE SCATTER PLOT FOR THE NUMBER OF ARTICLES AVAILABLE FOR EACH TYPE OF WASTE}

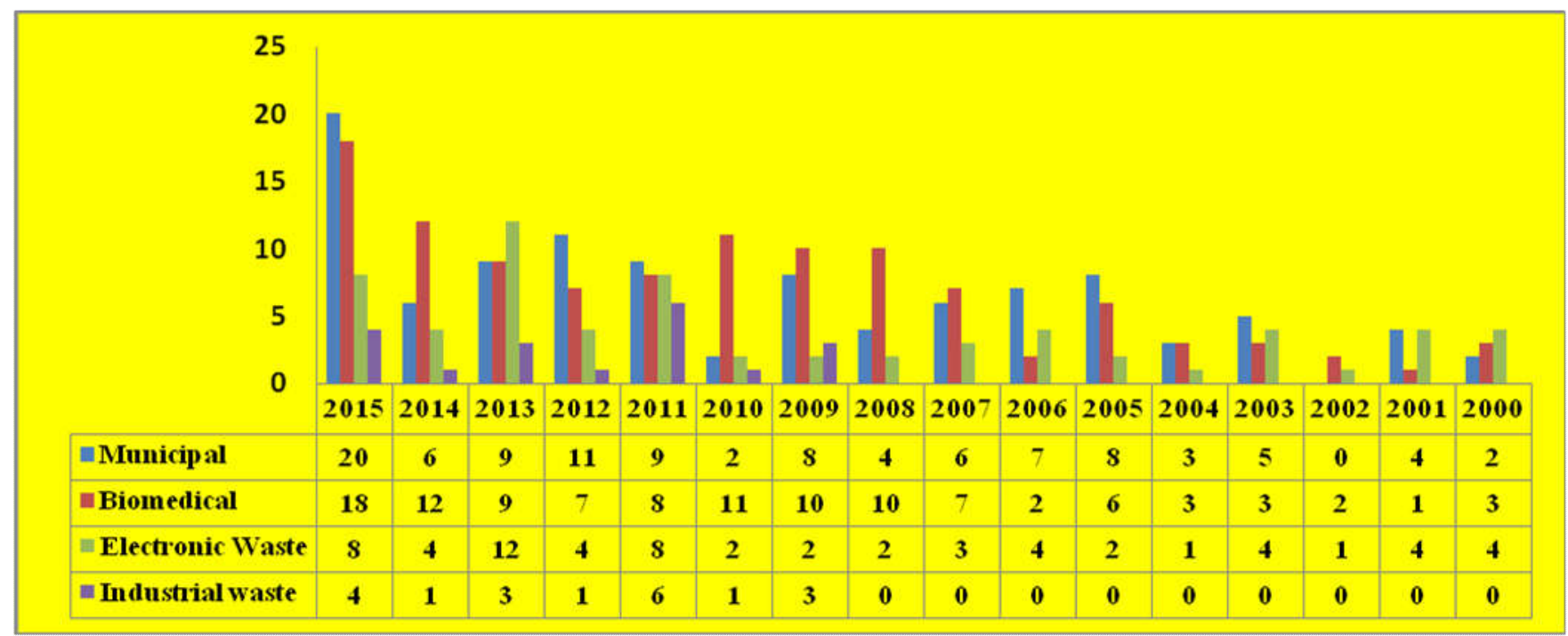

\section{RESULTS}

\section{Health center wastes \\ 1.1 Considering the impacts of health center wastes on human health}

Nowadays, inappropriate administration of hospital, healthcare, and clinical waste is not only threatening the health of mankind, but also polluting the environment. This can pose some problems for the health. As the concerns over different kinds of wastes have increased, World Health Organization (WHO) highlights that the medical waste should be controlled and managed ${ }^{1}$.The terms "clinical waste", "health care waste" and "medical / hospital waste" are often used in health care field and that is main reason for the significant restraint of utilizing and contrasting information from various nations. However, according to the data obtained from the ISI web of science, most of the papers with high citations are defined by health care wastes. In this paper, "health center wastes" is used as a current term to explain health center wastes.

Recently, various studies are carried out by the researchers in the developing countries over the management of waste in health centers due to the facilities within their countries. According to surveys, health center waste is one of the most perilous types of wastes because of all the pathogens and hazardous that consist of contagious, pathogenic, genotoxic, chemical and pharmaceutical substances, sharps, waste containing heavy metals, pressurized containers and radioactive substances ${ }^{4}$. About $10-25 \%$ of the total health centers' waste is hazardous. Some kinds of illnesses such as cholera, dysentery, skin infection and infectious hepatitis can spread epidemically ${ }^{5}$ Pruss A showed some of the potential microorganisms and the infected ways in the bodies of humans. Some infection types are gastro enteric infections, respiratory infections, AIDS and viral hepatitis A, B \& C.

There are some parameters that affect waste generation in health centers such as the size of the hospital (number of beds), hospital type, number of patients, number of employees, laboratory, operations theatres, bed occupency and hospital's division differences.

Because of the importance of this issue about health care, especially in the developing countries, they started to formulate general environmental legislations in countries such as Portugal, United Kingdom and France, a legislative context (ordinance) being applied since 1996, 1992 and 1997 respectively.

\subsection{Health center waste generation}

Fig 2 shows a summary of the attempts and their results in this field and waste generation in different countries listed as average $\mathrm{kg} /$ patient / day. 


\section{FIGURE II: TOTAL HEALTH CENTER WASTE PRODUCTION}

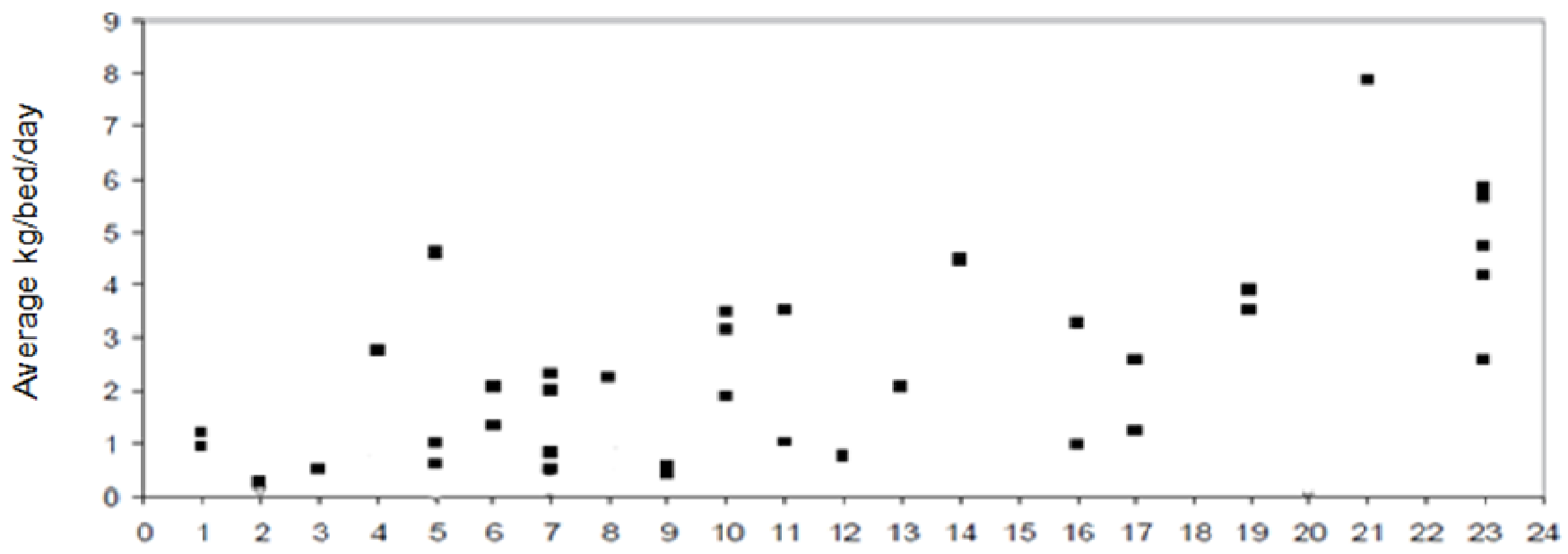

$\mathrm{N}=$ total healthcare waste; vertical columns are the ranges of data: 1-Bangladesh (including clinics), 2-Cambodia, 3-Lao PDR, 4-Nigeria, 5-Vietnam, 6-Pakistan, 7-India, 8-Guyana, 9-Philippines, 10- Jordan, 11- Colombia, 12- Peru, 13- Thailand, 14- Iran, 15- Bulgaria, 16- Brazil (including health centers and laboratories), 17-Turkey, 18-Taiwan (China), 19- Portugal, 20- Hong Kong (China), 21-Kuwait, 22-Italy, 23- The United States of America. Source: Emmanuel (2007). United States, Jordan, Kuwait, Greece and Taiwan are the highest medical waste generator countries (6) (WHO,2014).

\subsection{Suggested treatments for health center wastes}

Abundant researches have been conducted on health center waste management. Due to the whole results from the valued papers, the obtained conclusions are: Choosing the best management method according to the indices that effect waste generation in health centers such as (a) size of hospital (bed number), (b) hospital type, (c) number of patients, (d) number of employees etc.

Providing detailed legislations for health center waste management in order to manage wastes is an effective way ${ }^{7}$.

Lack of awareness about damages caused by the medical wastes to the environment and human's lives is one of the most critical reasons. Thus, education and training can be really effective in waste management and generation.

Using recycling or reusing programs and new methods such as SF-CO2 sterilization technology can be employed for managing solid waste ${ }^{8}$.

Attending to disposal methods by new policies and legislations in this field.

\section{Municipal wastes}

2.1 Considering the impacts of municipal wastes on human health

Population growth, industry advancement, new technologies, increasing consumption of resources, and industrialization has led to an increase in the quantity of wastes and toxics. Usually in the middle or low-income countries less attention has been paid to the factors affecting health and environment (e.g. waste) though municipal wastes can pose considerable risks to human health and environment if not managed properly ${ }^{9}$.

People are directly or indirectly exposed to the harmful effects of wastes. Directly via exposure to perilous material emissions from wastes and caused health problems, odors of wastes, vermin, and noise. Indirectly through the use of water, soil and agricultural plants infected with wastes.

Table I shows some of the threatening diseases by municipal wastes.

\section{TABLE I: SOME OF THE THREATENING DISEASES CAUSED BY MUNICIPAL WASTES}

\begin{tabular}{|l|}
\hline \multicolumn{1}{|c|}{ Municipal waste effects } \\
\hline $\begin{array}{l}\text { Respiratory symptoms and worse lung function, sore } \\
\text { throat, coughing in the morning, phlegm during the day, } \\
\text { phlegm for } 3 \text { months/year, coughing, wheezing } 10\end{array}$ \\
\hline $\begin{array}{l}\text { Impeding breathing, deteriorating health, body irritation: } \\
\text { vomiting, salivating, body itches, high blood pressure }\end{array}$ \\
\hline Cancer and non-cancer disease ${ }^{12}$ \\
\hline $\begin{array}{l}\text { Inhalation, dermal exposure, lower body weight }{ }^{13} \\
\text { Respiratory,dermatologic, and gastrointestinal health } \\
\text { effects, Bactria and fungi diseases, tightness of the } \\
\text { chest, nasal irritation, chronic cough, chronic phlegm } \\
\text { and bronchitis }{ }^{14}\end{array}$ \\
\hline
\end{tabular}




\subsection{Municipal waste generation}

Municipal waste generation in different nations depends on so many factors such as the economics, population, and industrialization. Fig 3 shows changes in the amounts of municipal waste generated per capita since 2000 . During the 1990s, municipal waste generated in the OECD area has risen $(+19 \%)$. As the early of 2000s, this enhancement has been slowing down $(+2 \%)$. Nowadays, the amount of the generated municipal waste surpasses the estimation of about 650 million tones. A person who lives in the area of OECD creates $52 \mathrm{~kg}$ waste on average every year; this is $20 \mathrm{~kg}$ more than its amount in 1990, but $30 \mathrm{~kg}$ less than in 2000 (OECD, 2015). Fig 4 shows the change in the amount of municipal waste generated per capita since 2000. According to the data, Norway has generated the highest amounts of municipal wastes during 2000s. Mexico is in the second place and Chile is the third. However, many countries such as the United States, New Zealand, Japan and Spain have successfully reduced the amount of municipals during recent years. decrease the effects of wrong waste disposal techniques on health.

The effects of new technologies for managing waste on health and the growing application of recycling and composting will need evaluation and observation ${ }^{15}$.

\subsection{Electrical wastes}

\subsection{Considering the impacts of e-wastes on human} health

Lately, the use of excessive electrical equipment has led to the creation of new kinds of wastes including household utilities, information technology and telecommunication tools, lighting utensils, electrical and electronic equipment, medical machines, observing and controlling instruments and automatic dispensers. Parts of electrical and electronic tools have been classified under activated glass, plastic coverings, batteries, cathode-ray tubes, circuit boards, as well as lead capacitors having chemical and toxic substances such as lead, aluminum, and silica in e-wastes. The interest for the realization of e-waste harmful effects on health and the environment has been wide spreading each day. Currently, the e-waste is one of

\section{FIGURE III: THE CHANGE IN THE AMOUNTS OF MUNICIPAL WASTE GENERATED PER CAPITA SINCE 2000}

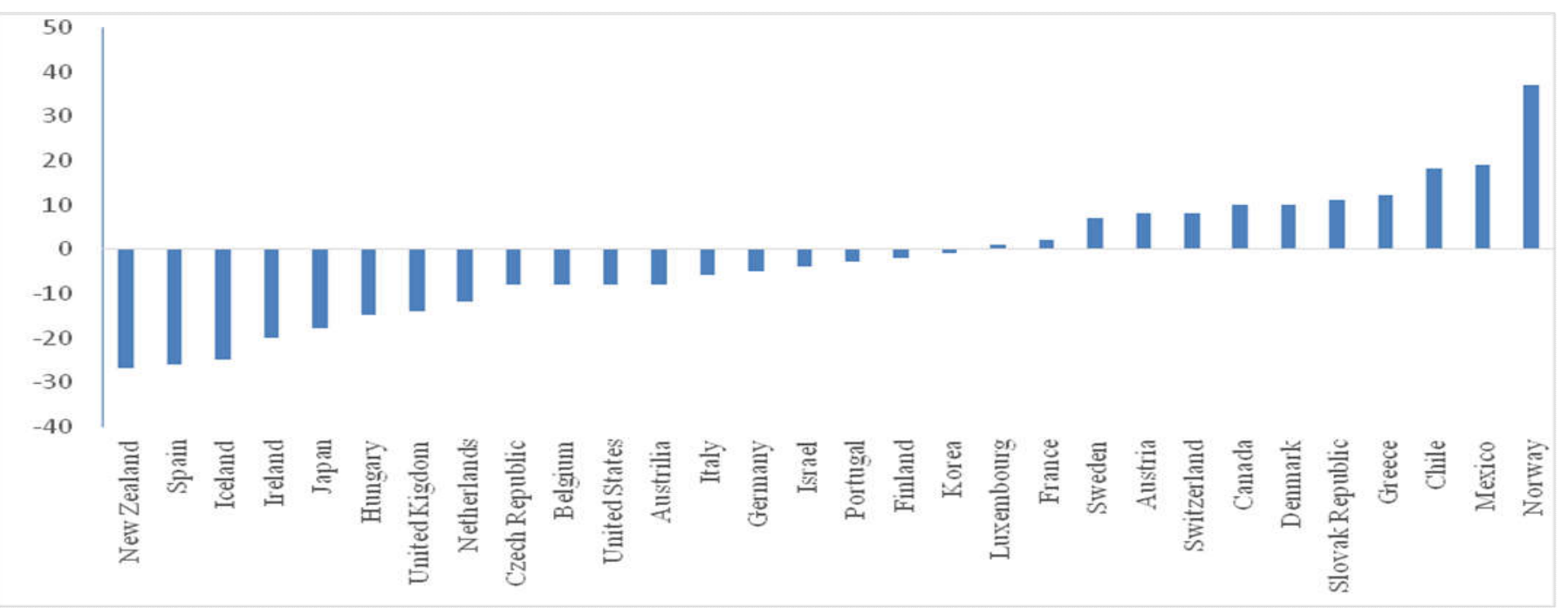

Source: OECD (2015), “Municipal Waste”, OECD Environment Statistics (database).

\subsection{Suggested treatments for municipal wastes}

Due to the whole results from the valued papers obtained, the proposals and conclusions are:

Occupational physicians are advised to treat those who are exposed to municipal wastes more vigorously.

The academic community should attempt to improve and find new solutions for discarding solid wastes. Use of properly operated and well equipped modern municipal waste incinerators and methods.

Immense investment on the facilities for managing waste, training, and education is mandatory to the quickest developing waste streams because of the high consumption volume of electrical appliances such as phones and computers. Numerous articles are published on the impacts of e-wastes ${ }^{16}$.

Electronic wastes, due to deadly chemicals are more dangerous than other wastes. Exposure to hazards is directly and indirectly (via inhalation, skin, contaminated water, soil, air and foods). Residents, women expecting children, old people, disabled human beings, fetuses, children and workers are more susceptible to these materials because added material during the process of recovery and recycling can 
cause complex and unknown combinations of toxicity. Many variables affect the exposure to e-wastes such as the length of exposure time, possible inhibitory, synergistic, or additive effects of several chemicals, routes and the resource of exposure.

Reported adverse effects of e-wastes are thyroid function change, changes in the function and expression of cells, adverse neonatal results, changes in personality and behavior, decreased lung function, reproductive health, growth, and mental health outcomes ${ }^{17}$.

\subsection{Electrical waste generation}

According to the latest data gathered from UNU-IAS SCYCLE (2015), the amounts of wastes generated in different countries are shown in Fig $4(\mathrm{~kg}$ per inhabitant). Norway, with $28.4 \mathrm{~kg}$ per inhabitant is the country with the highest amount of e-waste generation. Switzerland is in the second place with $26.3 \mathrm{~kg}$ per inhabitant and Iceland is the third with $26.1 \mathrm{~kg}$ per inhabitant.

\section{FIGURE IV:}

THE AMOUNTS OF E-WASTES GENERATED IN DIFFERENT COUNTRIES (KG PER INHABITANT)

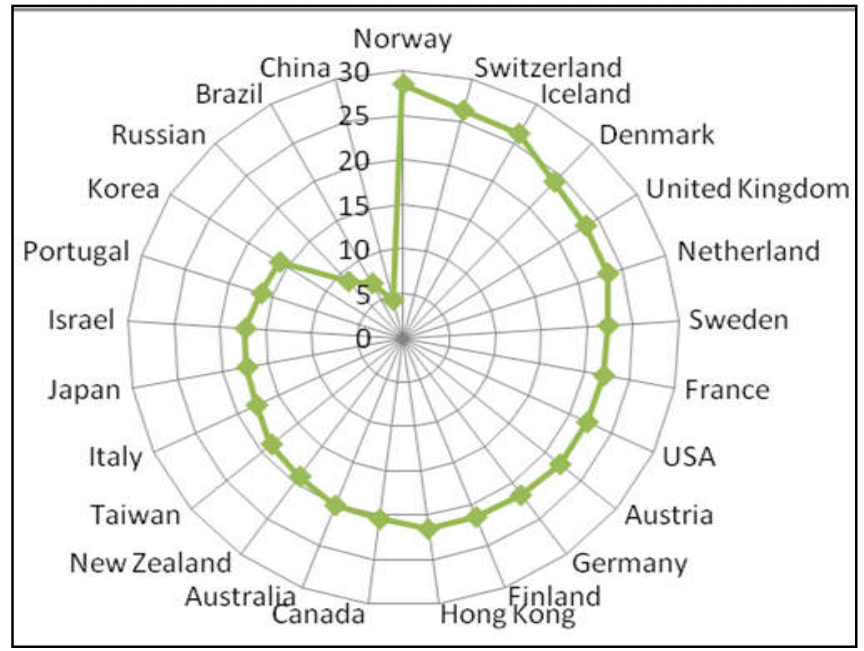

\subsection{Suggested treatments for e-wastes}

Due to the whole results from the valued papers, obtained proposals and conclusions are:

i) Effective environmental regulations in e-waste management in both developed and developing countries together with using new e-waste management systems ${ }^{18}$.

ii) Further investigation on potential health effects ${ }^{19}$.

lii) Since the e-waste is becoming a growing problem, the case study for similar e-waste activities will be needed to obtain accurate scientific conclusions ${ }^{20}$.

iv) Raising awareness, developing training methods and programs, creating policy solutions, educational programs and interventions to reduce e-waste exposures and its health effects.

\subsection{Industrial wastes \\ 3.4.1 Considering the impacts of industrial wastes on human health}

Nowadays, with rapid developments, the industries generate a variety of wastes. On the contrary, job creation and servicing will pollute the environment and endanger human health, air, water, and soil. Developed countries (e.g. Japan, the USA, China, and some European countries) are the chief producers of dangerous industrial wastes in the world ${ }^{21}$. They would worry about the effects that the wastes created by industrial processes will have on their health and environments. Thus, suitable waste management can be a step in this direction ${ }^{22}$.

Through the last few years, environmental authorities of a lot of industrialized countries have concentrated on the management of dangerous and industrial waste. Many retrospective epidemiologic researches have revealed a high frequency of idiosyncratic symptoms. The impacts of some toxic chemicals on children's health and development alongwith other vulnerable individuals is a distinctive concern, such as skin rash, headache, vertigo, insomnia and upper airway irritation. Table 2 shows the industrial waste effects according to the data collected.

\section{TABLE II: INDUSTRIAL WASTE EFFECTS ON HUMAN HEALTH}

\begin{tabular}{|l|}
\hline \multicolumn{1}{|c|}{ Diseases from industrial waste } \\
\hline Low birth weight ${ }^{23}$ \\
\hline $\begin{array}{l}\text { Liver dysfunction, arterial hypertension, hernia, } \\
\text { mood and personality disturbances, and genetic } \\
\text { mutations }{ }^{24}\end{array}$ \\
\hline $\begin{array}{l}\text { Respiratory tract, digestive system, and occasionally, } \\
\text { principally in children, cancers of skin along with } \\
\text { other skin illnesses }{ }^{25}\end{array}$ \\
\hline $\begin{array}{l}\text { Skin eruptions and illnesses, extreme fatigue, sleep } \\
\text { difficulties, upper respiratory infections, bronchitis, } \\
\text { otitis, allergies, and spontaneous abortion. }\end{array}$ \\
\hline
\end{tabular}

\subsubsection{Industrial waste generation}

Table 3 shows the countries industrial waste generation in 2011. According to the table, Asia pacific generates the highest amount of industrial wastes.

\subsubsection{Suggested treatments for industrial wastes}

Due to the conclusions from different papers, the treatment for the industrial wastes mentioned is as follows:

i) More studies, models, and solutions should be discussed for industrial wastes and hazardous materials for human health and environment. The epidemiologic investigation is more suitable for an evaluation of health hazards ${ }^{21}$. 
Effects of Exposure to a Variety of Waste on Human Health

TABLE III:THE GENERATION AMOUNT OF INDUSTRIAL WASTE IN 2011(MILLION TONS)

\begin{tabular}{|l|c|c|c|c|c|}
\hline \multicolumn{1}{|c|}{ Items } & Europe & Americas & $\begin{array}{c}\text { Africa and the Middle } \\
\text { East }\end{array}$ & Asia Pacific & \multirow{2}{*}{ Global } \\
\hline Generated & 1933.19 & 914.7 & 921.24 & 5357.46 & 9176.68 \\
\hline Collected & 1531.71 & 765.8 & 270.91 & 3346.02 & 5914.50 \\
\hline Key & Germany, UK & US, Brazil & South Africa, Saudi Arabia & China, Japan, India & \multirow{2}{*}{} \\
\cline { 1 - 4 } Countries & $\begin{array}{c}\text { France, Russia, } \\
\text { Bulgaria }\end{array}$ & $\begin{array}{c}\text { Canada, Chile, } \\
\text { Columbia }\end{array}$ & $\begin{array}{c}\text { United Arab Emirates, } \\
\text { Egypt, Tunisia }\end{array}$ & $\begin{array}{c}\text { South Korea, } \\
\text { Australia }\end{array}$ & \\
\cline { 1 - 4 }
\end{tabular}

Source ref: 27

ii) The regulatory requirements governing the management of hazardous wastes can influence the decisions of industrial facilities.

iii) Training industrial waste management methods ${ }^{28}$.

iv) Requiring high-tech industries (e.g. semiconductor and opto-electronics manufacturing) to conduct industrial waste recycling and cleaner production.

\section{CONCLUSION}

Due to the increase of a variety of wastes as well as undeniable negative effects on the environment and human health, proper management of waste production and awareness of its direct or indirect effects would be essential to take an action for reducing the effects on human health. Therefore, the main objective of the present article is to collect all information about the side effects of wastes in a single source and provide the possibility of their comparison for interested people.

According to the studies carried out in section 1 of the discussion part regarding the disposal of medical wastes, it is obvious that the America, Jordan, and Kuwait have the highest amounts of medical waste production. Thus, their people have more exposure to diseases such as respiratory problems, skin diseases, hepatitis A and B, cancer and so forth.

According to section 2 of the discussion part regarding municipal wastes, it is obvious that the highest municipal wastes are produced in countries such as Norway and Mexico. Their people are exposed to diseases such as breath, respiratory and reproductive problems.

According to section 3 of the discussion part regarding electrical wastes, it is also concluded that Norway has produced the highest amount of electronic waste. The people of this country are exposed to diseases such as thyroid, lung and reproduction problems.

According to section 4 of the discussion part, the amount of industrial waste production in Asia (countries such as China, Japan, South Korea, India and Australia) is higher than other Asian countries. Asian people, especially in advanced countries are prone to diseases such as respiratory problems, skin cancers, reproductive problems etc.

Finally for waste management and preventing damages to the environment and human health, the following approaches are proposed:

1. Development of new methods to deal with waste generation and waste management, especially in high-waste-producing countries mentioned (particularly Norway and Asian countries such as India, China etc.)

2. Extensive empirical studies over the impacts of wastes on human beings

3. Establishing rules regarding waste management, especially in high-waste-producing countries

4. Studying the effects of industrial waste, given that the articles published in this area are fewer

5. Public education for proper management of wastes to people \& staff etc.

\section{REFERENCES}

1. Laghari TM, Memon AA, Mustufa MA, et al. Assessment of Mass Level Public Awareness Campaigns Regarding Dengue among Parents Visiting Tertiary Care Children Hospital Karachi, Pakistan. JLUMHS. 2015;14(3):124-8.

2. Williams PT. Waste treatment and disposal: John Wiley \& Sons; Hoboken. 2013.

3. Sharma YC, Singh B, Madhu D, Liu Y, Yaakob Z. Fast synthesis of high quality biodiesel from 'waste fish oil' by single step transesterification. Biofuel Res J. 2014;1(3):78-80.

4. Mumtaz R, Khan AA, Noor N, Humayun S. Amalgam use and waste management by Pakistani dentists: an environmental perspective. East Mediterr Health J. 2010;16(3):334-9.

5. Prüss A, Giroult E, Rushbrook P. Safe management of wastes from health-care activities: World Health Organization; 1999. Available from: www.who.int/injection_safety/toolbox/docs/en/ waste_management.pdf

6. Windfeld ES, Brooks MS. Medical waste management-A review. J Environ Manage. 2015;163:98-108.

7. Caniato M, Tudor T, Vaccari M. International gov- 
ernance structures for health-care waste management: A systematic review of scientific literature. J Environ Manage. 2015;153:93-107.

8. Hossain MS, Santhanam A, Nik Norulaini NA, Omar AK. Clinical solid waste management practices and its impact on human health and environment-A review. Waste Manag. 2011;31(4):754-66.

9. Misra V, Pandey S. Hazardous waste, impact on health and environment for development of better waste management strategies in future in India. Environ Int. 2005;31(3):417-31.

10. Athanasiou M, Makrynos G, Dounias G. Respiratory health of municipal solid waste workers. Occup Med (Lond). 2010;60(8):68-23.

11. Ayomoh M, Oke SA, Adedeji W, Charles-Owaba $\mathrm{O}$. An approach to tackling the environmental and health impacts of municipal solid waste disposal in developing countries. J Environ Manage. 2008;88 (1):108-14.

12. Li H, Nitivattananon V, Li P. Municipal solid waste management health risk assessment from air emissions for China by applying life cycle analysis. Waste Manag Res. 2015;33(5):401-9.

13. Nouwen J, Cornelis C, De Fre R, et al. Health risk assessment of dioxin emissions from municipal waste incinerators: the Neerlandquarter (Wilrijk, Belgium). Chemosphere. 2001;43(4-7):909-23.

14. Perez HR, Frank AL, Zimmerman NJ. Health effects associated with organic dust exposure during the handling of municipal solid waste. Indoor and Built Environment. 2006;15(3):207-12.

15. Rushton L. Health hazards and waste management. British medical bulletin. 2003;68(1):183-97.

16. Julander $A$, Lundgren $L$, Skare $L$, et al. Formal recycling of e-waste leads to increased exposure to toxic metals: An occupational exposure study from Sweden. Environ Int. 2014;73:243-51.

17. Grant K, Goldizen FC, Sly PD, et al. Health consequences of exposure to e-waste: a systematic review. Lancet Glob Health. 2013;1(6):e350-e61.

18. Song $Q$, Li J. A review on human health consequences of metals exposure to e-waste in China.
Environ Pollut. 2015;196:450-61.

19. Lau WKY, Liang P, Man YB, et al. Human health risk assessment based on trace metals in suspended air particulates, surface dust, and floor dust from e-waste recycling workshops in Hong Kong, China. Environ Sci Pollut Res. 2014;21 (5):3813-25.

20. Xu X, Zeng X, Boezen HM, et al. E-waste environmental contamination and harm to public health in China. Front Med. 2015;9(2):220-8.

21. Li L, Wang $S$, Lin $Y$, et al. A covering model application on Chinese industrial hazardous waste management based on integer program method. Ecol Indic. 2015;51:237-43.

22. Usapein $P$, Chavalparit $O$. Options for sustainable industrial waste management toward zero landfill waste in a high-density polyethylene (HDPE) factory in Thailand. J Mater Cycles and Waste Manag. 2014;16(2):373-83.

23. Goldberg SJ, Lebowitz MD, Graver EJ, Hicks S. An association of human congenital cardiac malformations and drinking water contaminants. J Am Coll Cardiol. 1990;16(1):155-64.

24. Harris $\mathrm{RH}$, Highland JH, Rodricks JV, Papadopulos SS. Adverse health effects at a Tennessee hazardous waste disposal site. Hazardous Waste. 1984;1(2):183-204.

25. Health UDo, Services H. Agency for toxic substances and disease registry. Toxicological Profile for Asbestos Update Agency for Toxic Substances and Disease Registry. 1999.

26. Tovalín Ahumada H. Health conditions in a population living near an industrial waste recycling plant in Mexico. Rev Panam Salud Pública. 1998;3(3):152-7.

27. Song $Q$, Li J, Zeng X. Minimizing the increasing solid waste through zero waste strategy. J Cleaner Prod. 2015;104:199-210.

28. Cao P, Xia W, editors. Construction of the course of Industrial Waste Management. 2013 Conference on Education Technology and Management Science (ICETMS 2013); 2013: Atlantis Press.

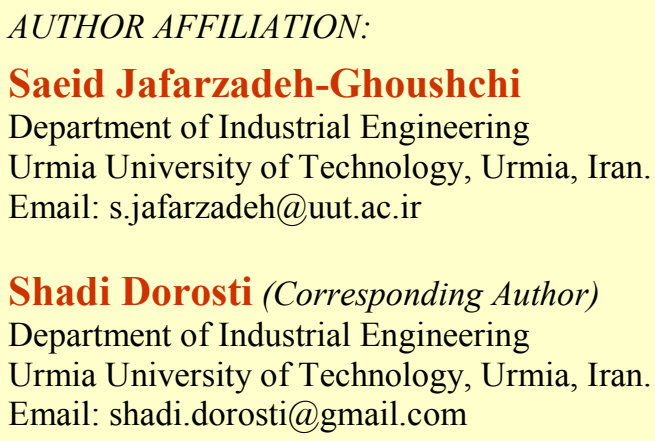

